\title{
ЦІННІСНО-ОРІЄНТОВАНА ОРГАНІЗАЦІЯ ДІЯЛЬНОСТІ СУЧАСНОГО УКРАЇНСЬКОГО РЕПЕРТУАРНОГО ТЕАТРУ
}

\author{
Коваль І.М., директор Харківського академічного театру \\ музичної комедії, здобувач (ХНУБА)
}

\begin{abstract}
Статтю присвячено проблемі пошуку концепиії організації діяльності такого соціального інституту, як сучасний украйнський репертуарний театр. Останній гине з-за протиріччя між статусною його неприбутковістю, підтриманою бюджетним фінансуванням, та ринковим устроєм середовищ життєдіяльності. Однією з можливих концепцій тут може бути ціннісно-орієнтована організація діяльності репертуарного театру. За таких умов виникає доцільність прийняти в якості центрального показника діяльності театру його творчо-виробничий потенціал, який потребує напрацюювання відповідних компетенцій та компетентностей.
\end{abstract}

Ключові слова: сучасний украӥнський репертуарний театр, організація діяльності, ціннісно-оріснтоване управління, творчо-виробничій потенціал, компетенції та компетентності

\section{ЦЕННОСТНО-ОРИЕНТИРОВАННАЯ ОРГАНИЗАЦИЯ ДЕЯТЕЛЬНОСТИ СОВРЕМЕННОГО УКРАИНСКОГО РЕПЕРТУАРНОГО ТЕАТРА}

\author{
Коваль И.Н., директор Харьковского академического театра \\ музыкальной комедии, соискатель (ХНУСА)
}

\begin{abstract}
Статья посвящена проблеме поиска концепции организаџии деятельности такого сочиильного института, как современный украинский репертуарный театр. Последний погибает из-за противоречия между статусной его неприбыльностью, поддержанной бюджетным финансированием, $u$ рыночным укладом сред жизнедеятельности. Одной из возможных концепций здесь может быть иенностноориентированная организация деятельности репертуарного театра. При таких условиях возникает иелесообразность принять в качестве иентрального показателя деятельности театра его творчески-производственный потенциал, который требует наработки соответствующих компетенций и компетентностей.
\end{abstract}

Ключевые слова: современный украинский репертуарный театр, организация дея-тельности, ценностно-ориентированное управление, творчески производственной потенциал, компетенции и компетентности

\section{VALUABLE-ORIENTED ORGANIZATION OF ACTIVITY OF MODERN UKRAINIAN THE REPERTOIRE THEATER}

\author{
Koval I.N., director of the Kharkiv Academic Theater \\ musical comedy, competitor (KHNUCA)
}

The article is devoted to the problem of searching the organizing conception of the activity of such social institution as the modern Ukrainian repertoire theater. The last one 
perishes because of the contradiction between its statutory unprofitability, supported by budgetary financing, and the market structure of living environments. One of the possible concepts here can be a value-oriented organization of the repertory theater. The unconditional value of the theater is its organizational culture. Its formation requires a balanced use of motives and stimulus. Under such conditions it is advisable to take as its central index the creative and production potential that requires the development of appropriate competencies and competences. The potential is determined by both the resource base and the possible efficiency of its use. Therefore the indicator characterizing the potential of the theater is represented by the vector quantity. An analytical description of this quantity is proposed in the article. The matrix "Resource-sufficiency / Efficiency of resource use" is proposed for the purpose of developing managerial decisions on further increasing the creative and productive potential of both the employee and the theater troupe. The unconditional sign of the development of the theater is the positive dynamics of its creative and production potential. Only with such dynamics is the competitiveness of the repertory theater in market economy ensured.

Keywords: modern Ukrainian repertoire theater, organization of activity, valueoriented management, creatively productive potential, competence and competence

Постановка проблеми. Проблема виживання і подальшого розвитку стала нагальною для сучасних українських репертуарних театрів, які згідно із (рамковим, бо не дає відповіді на всі виникаючі питання) Законом [1] $\epsilon$ неприбутковими організаціями i тому існують за бюджетні кошти, але зо всіх сторін оточені ринковими відносинами. Вирішення озвучено проблеми потребує пошуку нових підходів до управління театрами. Один i них може бути започаткованим на ідеї так званого valuebased management (в перекладі управління, що спрямоване на створення цінності), що «працює» вже достатньо давно, бо «...забезпечує точну та недвозначну метрику - цінність, - на яку налаштовується діяльність всієї організації» [2, С. 87]. Але при такому управлінні реально враховуються, поперш за все, інтереси (цінності) власників справи (бізнесу). А для них, що $\epsilon$ достатньо природним, найвища цінність це майбутня вартість справи (бізнесу). Тому в україномовних виданнях valuebased management (VBM) сприймається як вартісно-орієнтоване управління [3]. Між тим, в житті суспільства існують і такі справи, в яких пріоритетними є ціннісні, а не вартісні показники. До таких повною мірою відноситься театральна справа, в межах якої існують репертуарні (неприбуткові) театри. Для них VBM повинне сприйматися в первозданному вигляді. На жаль, публікації 3 цього питання відсутні. Тому розробка проблеми $V B M$ для таких суб'єктів господарювання уявляється вкрай актуальною.

Аналіз останніх досліджень i публікацій. Публікації з питань ціннісноорієнтованого управління репертуарними театрами автору даної роботи невідомі. Між тим, заслуговує на увагу дослідження автора публікації [4], який вивчав соціологічні аспекти ціннісноорієнтованого менеджменту у міжнародних неприбуткових недержавних організаціях, щоб винайти засоби узгодження інтересів різних соціальних спільнот та кіл, ритмів їхнього функціонування.

Виділення невирішених частин загальної проблеми. 3 огляду на доступну інформацію можна стверджувати, що проблеми ціннісноорієнтованої організації діяльності сучасного українського репертуарного театру ще чекають свого часу та дослідників.

Метою даної статті $\epsilon$ попередній пошук шляхів для розбудови ціннісно- 
орієнтованої організації діяльності сучасного українського репертуарного театру, який $\epsilon$ неприбутковою організацією, що працює за ринкових умов.

Виклад основного матеріалу дослідження. Вперше ідея ціннісноорієнтованого управління 3'явилася у західних корпораціях як противага управлінню, стрижнем якого виступало бюджетування. Головною метою стало забезпечення цінності для акціонерів, ключовим вимірювачем якої $\epsilon$ сумарна доходність акціонерів [5, С. 35]. Це виключно фінансовий показник, який вимірює дохід в грошових одиницях, що здобувають акціонери від володіння акціями компанії. Ясно, що цей підхід не може використовуватися таким суб'єктом господарювання, як репертуарний театр, для якого дохід не є головним завданням його існування.

Разом 3 тим, будь-яке управління справою завжди є цілеспрямованим [6, С.359; 7, С. 96]. Але саме «якість» цілі, iï суб'єктність (а не пї масштаб) визначає пріоритетність зусиль суб'єкту господарювання [8, С.8]. Тому можна погодитися 3 тим, що «якісні» цілі відшукуються внаслідок ціннісного вибору саме суб'єкту господарювання, якщо під цінністю у широкому (життєвому) сенсі розуміти уявлення про найкраще, саме важливе, заради чого доцільно працювати, жертвувати часом, силами і чимось ще $[8$, С. 16]. 3 огляду на саме таке розуміння цінностей, останні можна сприймати у якості напрямку нескінченного руху, а цілі при цьому - як плановані, добре вимірювані результати, окремі пункти (зупинки) на траєкторії цього руху (див. рис. 1).

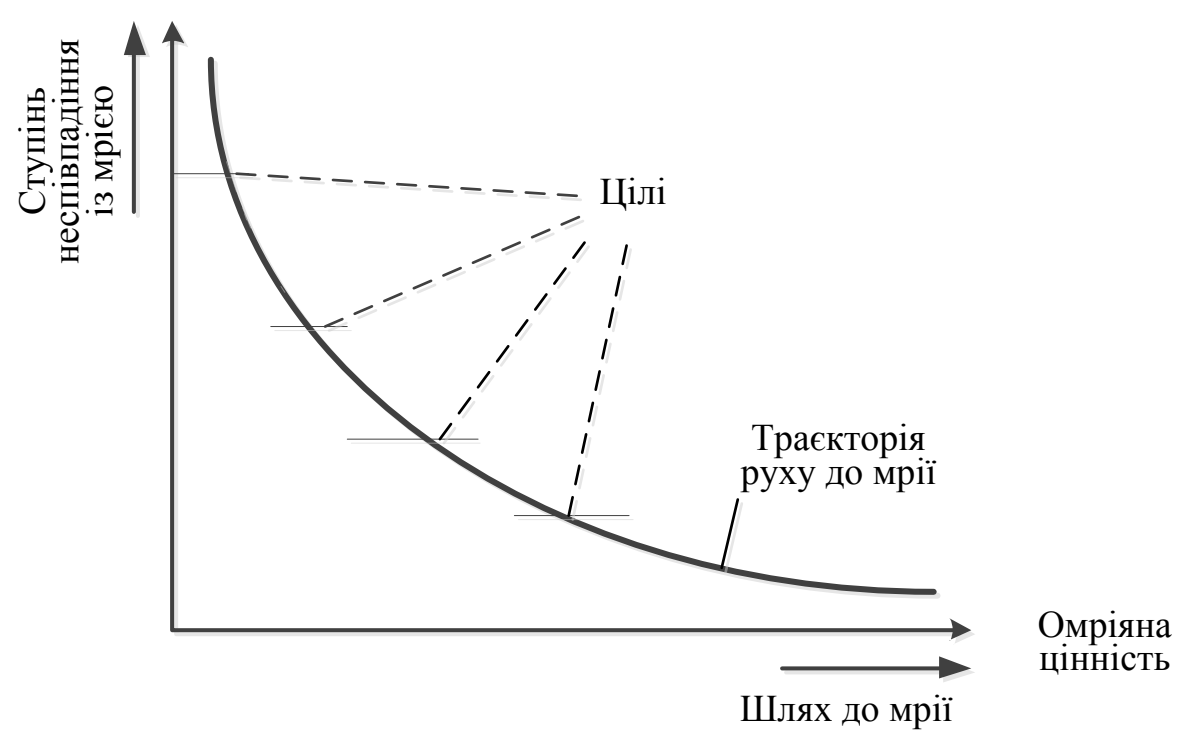

Рис. 1. Пояснення змістовного наповнення дефініцій «ųiнність» та «и̧іль» (розроблено на базі ідей роботи [8])

По життю людина вибудовує для себе цілі, які збуджуються цінностями, заради просування до них [8, С. 17]. В якості цінності для людини може виступати благо, під яким розуміється все те, що дозволяє людині нівелювати нестатки факторів (речей), відсутність яких робить неможливою життєдіяльність цієї людини [8, С. 26]. Такий збіг обставин збуджує внутрішню готовність людини до дій задля здобуття цінності-блага; таку готовність назвали внутрішньо усвідомленим спонуканням або мотивом [9, С. 56-57]. Зовнішне несилове (як правило, за рахунок економічних важелів) спонукання людини до дій іншою людиною називають стимулом (подразником) [9, С. 83-84]. 
Будь-яка людська цінність може мати наступні складові [10, С. 301-302]: (1) інтелектуальну, заради якої людина готова зануритися в діяльність в галузі фундаментальної науки або філософії; (2) економічну, коли людина вище за все цінить те, що корисно і вигідно; (3) естетичну; проявляється в тому, як людина віддає перевагу формі та гармонії; (4) соціальну; проявом іiі $\epsilon$ потреба у любові людей (соціуму); (5) політичну; ознакою іiі $\epsilon$ важливість причетності до влади; (6) релігійну; особа 3 цією домінантою бачить в світобудові єдність і вищий сенс. Відмінності ступеня вираженості даних шести ціннісних орієнтацій визначають тип ціннісних уподобань особистості (або іiі ціннісної матриці, яка згодом формує соціокультурну матрицю [11]); цей тип потім може визначати відповідний тип ціннісних уподобань соціуму (або колективу театру), який можна назвати його соціоціннісною матрицею.

В роботі [10] стверджується (див., наприклад, [10, С. 307]): «..особистість це те, що дозволяє нам передбачити поведінку людини у певно визначеній ситуації». Взаємодії між системою цінностей особистості і більш об'ємною соціоціннісною матрицею колективу театру визначають зміст того, що прийнято називати організаційною культурою («душею» театру) [12]. До їі основних ознак (складових) відносять [13, C. 299-309]:

- відображення в місії (філософії існування) театру його основних цілей;

- спрямованість на вирішення інструментальних (виробничих в широкому сенсі) завдань театру або особистих проблем його працівників;

- ступінь ризиків в життєдіяльності театру;

- міра співвідношення конформізму та індивідуалізму;

- перевага групових або індивідуальних форм ухвалення рішень;

- ступінь підлеглості планам та регламентам;

- переважання співпраці або суперництва серед членів колективу;

- відданість або байдужість людей стосовно театру;

- орієнтація на самостійність, незалежність або підлеглість;

- характер ставлення керівництва до персоналу театру;

- орієнтація на групову або індивідуальну організацію праці та стимулювання; зміни;

- орієнтація на стабільність або

- джерело та роль влади в театрі;

- засоби інтеграції;

- стилі управління, відносини між працівниками та керівництвом театру, способи оцінки працівників.

Оргкультура театру містить як суб'єктивні, так і об'єктивні елементи.

До суб'єктивних елементів культури належать вірування, цінності, образи, ритуали, табу, легенди та міфи, пов'язані з історією театру та життям його засновників, звичаї, прийняті норми спілкування, гасла.

Організаційну культуру театру доцільно розглядати в якості організаційної цінності [14, С. 172], що $є$ джерелом організаційних мотивів, які виступають в якості підгрунтя для методологічного забезпечення управління діяльністю театру [11, С. 64].

При формуванні організаційної культури можуть використовуватися i мотиви, i стимули. На рисунку 2 зображено, що у випадку привілейованості у зацікавленої сторони (працівника) матеріальних потреб та цінностей, доцільно застосовувати стимулювання, тобто впливати на людину за допомогою потребно-значущого для нього зовнішнього предмета (об'єкта, умов, ситуації тощо), що спонукає людину до певних дій (перебування в комфортних умовах і т.п.). 


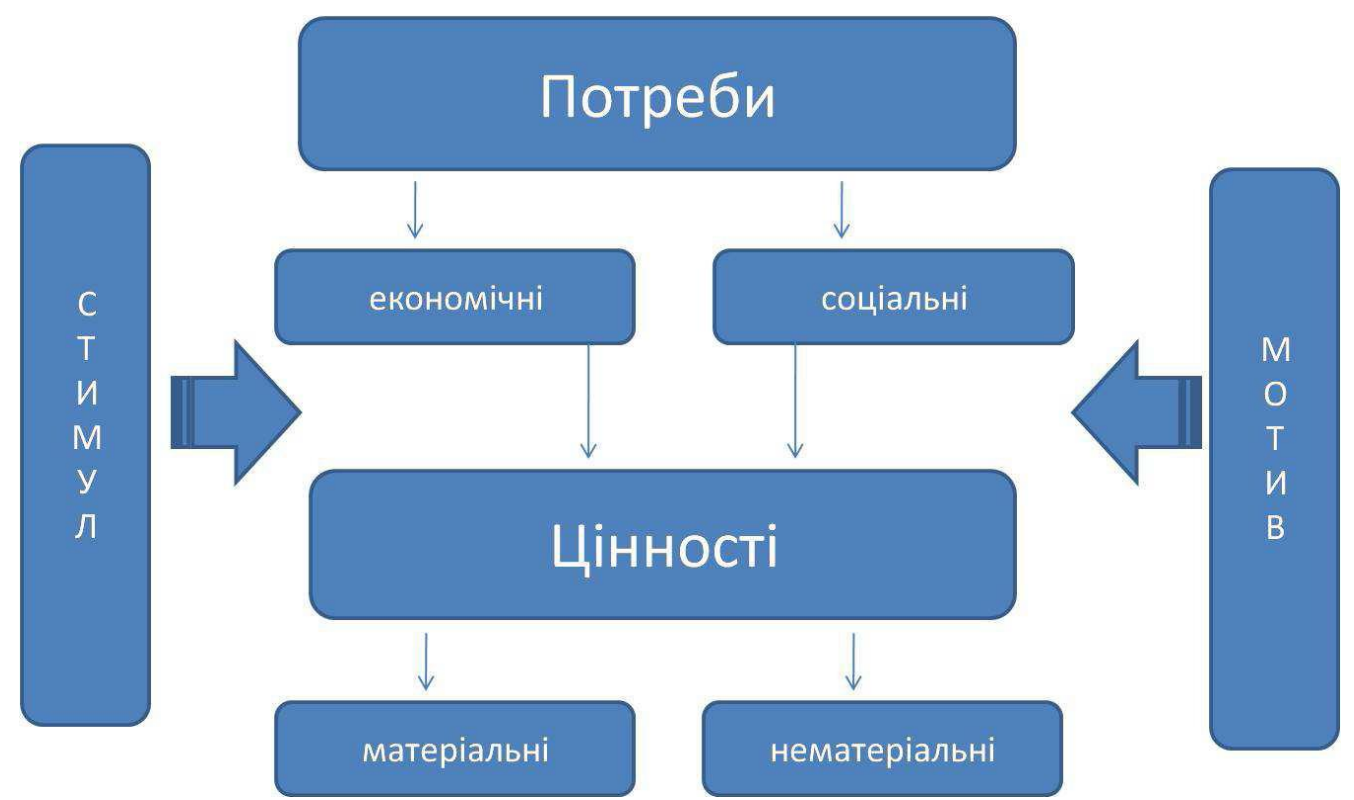

Рис. 2. Місие мотиву та стимулу, як факторів впливу на людину [15, С. 53]

Відповідно, якщо переважають соціальні цінності, то краще застосовувати мотивацію (як процес), а саме емоційночуттєвого зіставлення образу людської потреби з образом зовнішнього предмета (претендента на предмет потреби) та через внутрішній психічний механізм людини, який забезпечує впізнання предмета відповідного потребі відбудеться запуск спрямованої поведінки для досягнення своєї мети (яка відповідає потребі) [15, С. 53]. Відзначені процеси мотивації та стимулювання при формуванні організаційної культури, без сумніву, є об'єктами управління, яке можна назвати ціннісно-орієнтованим. Одним із базових принципів у ньому - баланс тілесного із духовним.

Економіко-теоретичне трактування цінності пов'язується із ступенем корисності блага, за допомогою якого людина нівелює нестачу дуже важливих факторів (речових, енергетичних та інформаційних засобів), що забезпечують iii життєздатність. Карл Менгер ще у 1901 році писав [16, С.65]: «Ті предмети, які мають здатність бути поставленими в причинний зв'язок із задоволенням людських потреб, ми називаємо корисностями; і так як ми розпізнаємо цей причинний зв'язок, і водночас маємо змогу дійсно застосувати дані предмети для задоволення наших потреб, то ми називаємо їх благами». I далі: «Цінність це значення, яке мають для нас конкретні блага або їх певна кількість внаслідок того, що у задоволенні своїх потреб ми усвідомлюємо залежність від наявності їх у нашому розпорядженні» [16, с. 94].

Дещо далі у трактуванні соціальноекономічної природи цінності пішов учень К. Менгера - Є. фон Бем-Баверк, який обгрунтував суттєву відмінність між поняттями «цінність» і «корисність». Він запропонував під «корисністю» розуміти здатність певної речі служити певною мірою для людського благополуччя, а під «цінністю» - те, що ця річ (потенційно) здатна задовольнити нагальні потреби конкретного індивіда. Може бути так, що річ для людини може бути корисною, але не буде цінною. Тобто, С. фон Бем-Баверк виділив у природі цінності іiі соціальноекономічну сутність, диференціювавши іiі на суб'єктивну (цінність певного матеріального блага для конкретної людини як члена соціуму) та об'єктивну (цінність речі як суспільного блага, що дає змогу обмінювати іiі на певну кількість інших матеріальних благ) [17, с. 248]. У 
сучасному трактуванні природи цінності суб'єктивну цінність ще називають індивідуальною цінністю або індивідуально-груповою. Вона проявляється на певному сегменті ринку (у відносно однорідній за потребами і вподобаннями групі споживачів). Саме вміння вірно оцінити розмір такої групи $\epsilon$ надважливою (однією із ключових) компетенцією, яка дає змогу керівництву сучасного українського репертуарного театру приймати правильні рішення щодо перспективності постановок нових спектаклів.

Необхідно зазначити, що на пострадянському просторі категорія «цінність» достатньо часто підміняється категорією «вартість» (дебати 3 цього приводу у фахових виданнях виникають постійно [18]). Зазвичай у вітчизняній науковій літературі термін «value» при перекладах праць всесвітньо відомих економістів-теоретиків в основному трактується не як «цінність», а як «вартість». В результаті виникає плутанина в поняттях. Більшість вітчизняних фахівців сприймають ці терміни як синоніми, які можна застосовувати в залежності від доцільності застосування. Насправді принципово важливо чітко визначати і розмежовувати ці два поняття. Питання не просто в назві, питання в суті справи. Тут важливо визначитися, що повинні нарощувати управлінці для власників справи: цінність або вартість?

В роботі [19] пропонується сприймати категорію «цінність» як висвітлення сутності можливостей економічного об'єкта щодо доступу або формування грошових потоків, а термін «вартість» - в якості оцінки витратної його сутності. Під цінністю справи пропонується розуміти іiі виробничий потенціал, що визначається у здатності генерувати вільний грошовий потік для власників (для театру - касові збори). Вимірюється цінність справи за допомогою дисконтування очікуваного грошового потоку на момент оцінки 3 урахуванням ризику, що пов'язаний із невизначеністю отримання майбутніх результатів. Така оцінна технологія здобула назву дохідного підходу до оцінки [20; 307], результати якої вимірюються у грошових одиницях, що насправді дуже зрозуміло i прийнятно для власників справи та можливих іiі інвесторів (тут використовують дефініцію «інвестиційна привабливість»).

За вказаних умов ціннісноорієнтований підхід до управління театральною справою - це цілеспрямований процес, направлений на зростання цінності цієї справи як для власників i інвесторів, так i для працівників, контрагентів та суспільства, а також підвищення його ринкової вартості шляхом реалізації потенціалу конкурентних переваг, пов'язаних 3 наявними активами (використовуваним капіталом будь-якої природи) суб'єкту господарювання.

Творчо-виробничий потенціал театру суттєво залежить від компетенцій та компетентностей (компетенція - це коло питань у певній галузі, по яких суб'єкт добре обізнаний та досвідчений, а компетентність - здатність (уміння) діяти на основі здобутих компетенцій [21]), що складають зміст його цінності як в особистому, так і в суспільному плані.

Під цінністю театральної справи доцільно розуміти творчо-виробничий потенціал театру, під яким можна розуміти реальну або ймовірну спроможність театру (або іï структурних складових) виконувати цілеспрямовану роботу (саме таке визначення дає і Боб Райан [22, С.61]). При цьому потенціал буде визначатися як самою ресурсною базою (до якої повинна залучатися i театральна трупа), так i можливою ефективністю ії використання.

Ефективність будь-якої діяльності $\epsilon$, як відомо, величиною векторною [23], в якості координат якої виступають показники результативності, 
ресурсоємності та часу досягнення результату. 3 цих причин потенціал театру також повинен бути величиною векторною, координатами якої можуть бути обсяги ресурсів та ефективність їх використання. При такому визначенні потенціалу-цінності театру з'являється природна можливість для його вимірювання, а 3 останнім - і ціннісноорієнтоване управління театром.

Одним 3 можливих варіантів для вимірювання та управління можуть бути відносні показники потенціалу Bnn, ресурсозабезпеченості $B n p$ та ефективності використання ресурсів Впеф особистості (працівника), які можуть бути визначеними наступним чином:

$$
B n n=B n p * \text { Bneф },
$$

$$
\begin{aligned}
\text { Bnp } & =\frac{\Pi p \phi}{\Pi p n}, \\
B n e \phi & =\frac{\Pi e \phi \phi}{\Pi e \phi n},
\end{aligned}
$$

де Прф і Прn - відповідно фактичне i планове значення показника ресурсозабезпеченості театру, Пефф $\mathrm{i}$ Пефn - відповідно фактичне і планове зачення показника ефективності використання ресурсів у театрі.

Для розробки управлінського рішення з приводу подальшого нарощення потенціалу працівника театру можна скористатися матрицею «ресурсозабезпеченість / ефективність використання ресурсів», приклад якої наведено на рисунку 3.

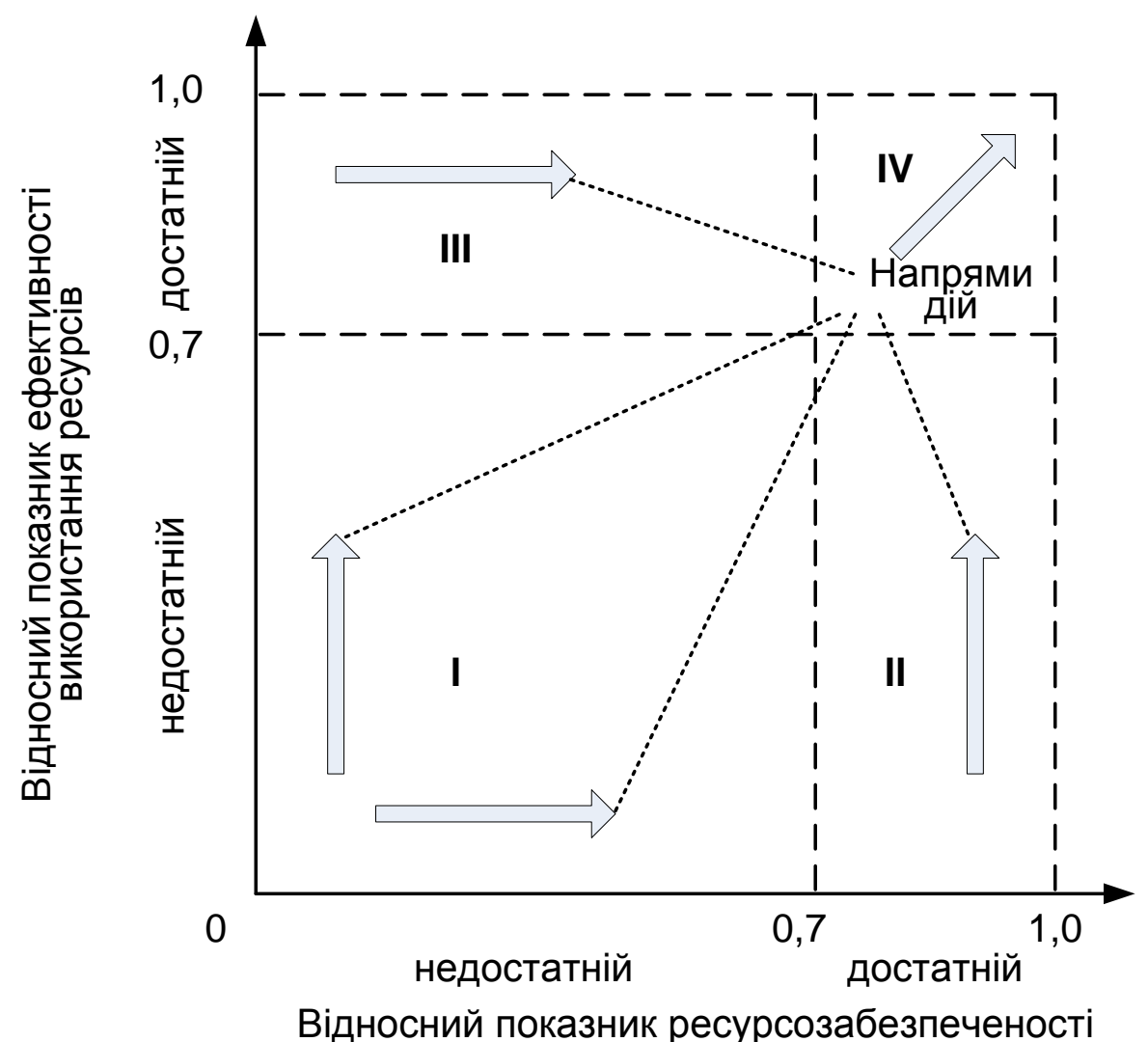

Рис. 3. Матриия «ресурсозабезпеченість / ефективність використання ресурсів» (авторська розробка)

У наведеному прикладі межу відносного показника потенціалу Bnn на «достатній / недостатній» встановлено у рівні 0,5.

припущенні необхідності забезпечення Для визначення векторного 
показника потенціалу (цінності) координат у вигляді так званої кругової «ансамблю» суб'єктів господарювання діаграми спрямованості (див. рисунок 4), (працівників, підрозділів) в театрі його яку назвемо багатокутником (або $n$ доцільно відображати в полярній системі кутником) потенціалу «ансамблю».

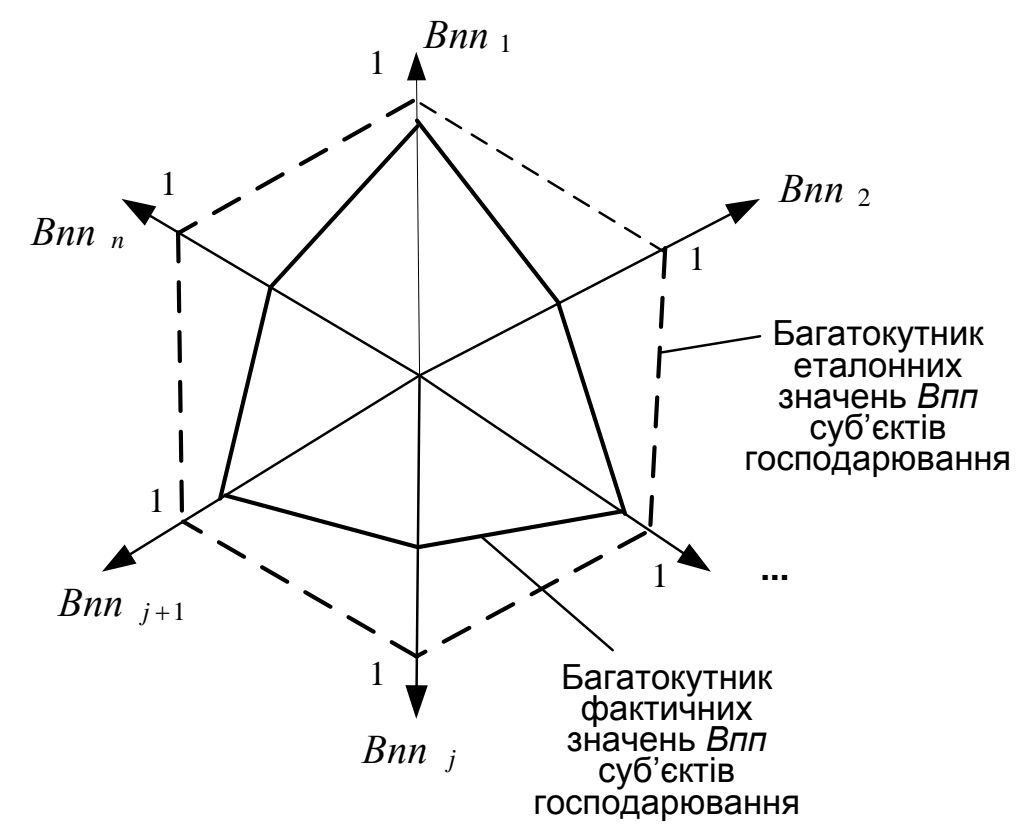

Рис. 4. Багатокутник потенціалу (иінності) «ансамблю» (авторська розробка)

Якщо всі $n$ показників учасників «ансамблю» матимуть нормований характер, то відношення площини, яку займає багатокутник фактичних значень Bnn суб'єктів господарювання,

$$
S=\frac{1}{2} \sum_{j=1}^{j=n} B n n_{j} \cdot B n n_{j+1} \cdot \sin \frac{2 \pi}{n}
$$

до площини, яку займає багатокутник еталонних значень Bnn суб'єктів господарювання,

$$
S_{\text {еталон }}=\frac{n}{2} \cdot \sin \frac{2 \pi}{n}
$$

буде свідчити про відносне значення показника потенціалу (цінності) «ансамблю», тобто

$$
\text { Вип анс }=S / S_{\text {еталон }}
$$

Визнаною ознакою розвитку театру повинна бути позитивна динаміка його потенціалу(цінності). Щоб визначитися 3 переліком показників цінності при плануванні проектів розвитку театру спочатку слід визначитися з цілями, що ставляться перед проектами, та факторами, які забезпечують досягнення цілей, а також факторами, які свідчать про досягнення цілей. Їх можна називати відповідно факторами-створювачами та факторами-визначальниками [24, С.45]. До факторів-визначальників можна, наприклад, віднести обсяги та структуру репертуару, канали його просування до глядачів, мотивацію персоналу, контроль якості творчо-виробничих процесів та все таке інше, що допомагає створювати сучасну цінність театру. Фактористворювачі мають довготерміновий вплив на майбутню цінність театру. До них можна віднести формування майбутньої конкурентоспроможності театру за рахунок проведення i впровадження інновацій, формування та розвитку ключових компетенцій та таке інше.

Висновки. Підсумовуючи вище викладене, можна дійти до тверджень: (1) ідея ціннісно-орієнтованої організації діяльності сучасного українського репертуарного театру може бути цілком 
дієздатною; (2) реалізація ідеї $V B M$ в галузі театральної справи $є$ фактично іï подальшим розвитком; (3) ціннісноорієнтований підхід до управління театральною справою повинен бути цілеспрямовано-позитивним і невпинним процесом, який забезпечить розвиток цієї справи; (4) головною цінністю театральної справи $\epsilon$ творчо-виробничий потенціал театру, під яким можна розуміти реальну або ймовірну спроможність театру (або його структурних складових) виконувати цілеспрямовану роботу; (5) потенціал театру суттєво залежить від компетенцій та компетентностей, які і складають зміст його цінності.

\section{ПЕРЕЛІК ВИКОРИСТАНИХ ДЖЕРЕЛ}

1. Закон України «Про театри i театральну справу» (Відомості Верховної Ради (ВВР), 2005, № 26, ст.350)\{ІІ3 змінами, внесеними згідно із Законами № 3421-IV від 09.02.2006, BBP, 2006, № 22, ст.199 N 5461-VI від 16.10.2012, ВВР, 2014, № 5, ст.62 № 406-VII від 04.07.2013, BВP, 2014, № 20-21, ст.712 № 911-VIII від 24.12.2015, ВВР, 2016, № 5, ст.50 № 955VIII від 28.01.2016, ВВР, 2016, № 10, ст. 103$\}$

2. Koller T. What is value-based management? [Text] / Timothy Koller // The McKinsey Quaeterly.- 1994.- N 4.- P. 87 101.

3. Крейдич I.М. Проблеми

вартісно-орієнтованого управління розвитком підприємства. [Текст] / I.М.Крейдич, А.О. Гагарін // Економічний вісник НТУУ «КПІ».- 2016.- № 13.- С. $208-212$.

4. Буко С.Л. Ціннісні орієнтири сучасного менеджменту: автореф. дис. на здобуття вчен. ступ. канд. соціолог. наук: 22.00.04 [Текст] / С.Л. Буко; Інститут соціології Національної академії наук України, Київ, 2009.- 18 с.

5. Эшуорт Г. Менеджмент, основанный на ценности (Value-based management): Как обеспечить ценность для акционеров. [Текст] / Гари Эшуорт, Джеймс Пол; пер. с англ.- М.: ИНФРА-М, 2006.- 190 c.

6. Друкер П. Менеджмент. [Текст] / Питер Друкер, Джозеф А. Макьярелло; пер. с англ.- М.: ООО «И.Д. Вильямс», 2010.- $704 \mathrm{c}$.

$$
\text { 7. Дункан Дж. У. }
$$

Основополагающие идеи в менеджменте. Уроки основоположников менеджмента и управленческой практики. [Текст] / Джек У. Дункан; пер. с англ.- М.: Дело, 1996.$272 \mathrm{c}$.

8. Пригожин А.И. Цели и ценности. Новые методы работы с будущим. [Текст] / А.И. Пригожин.- М.: Издательство «Дело» АНХ, 2010.- 432 с.

9. Ильин Е.П. Мотивация и мотивы. [Текст] / Е.П. Ильин. - СПб.: Питер, 2006.- 512 c.

10. Хьелл Л.А. Теория личности. [Текст] / Ларри А. Хьелл, Дэниел Дж. Зиглер; пер. с англ.- СПб.: Питер, 2002.$608 \mathrm{c}$.

11. Дрожжина E.Е. Матрица социолизации личности в социокультурной среде университета. [Текст] / Е.Е. Дрожжина // Вестник Волгоградского государственного университета.- Серия 7. Философия.2011.- № 1 (13).- С. 132 - 137.

12. Сєріков А.В. Організаційна культура як домінанта в життєдіяльності підприємства: системний підхід. [Текст] / А.В. Сєріков, А.Т. Атреп'єва, А.М. Боженко, Ю.В.Маренич, Ю.О. Рябуха, С.С. Сергеєв // Бізнес Інформ.- 2014.- № 1.- С. $192-198$.

13. Смирнов Э.А. Основы теории организации: Учеб. Пособие для вузов. / Э.А. Смирнов.- М.: ЮНИТИ, 2000.- 375 с.

14. Кучин С.П. Економічні засади розвитку суб'єктів соціально-культурної інфраструктури в Україні: монографія, видання друге. [Текст] / С.П. Кучин.Харків: СПДФО Добринін В.С., 2013.- 356 c.

15. Рич М. І. Мотивація як основа консолідації цінностей зацікавлених 
сторін у проекті [Текст] / M. I. Рич // Управління розвитком складних систем. 2016. - Вип. 25. - С. 51-57. - URL: http://nbuv.gov.ua/UJRN/Urss_2016_25_10.

16. Менгер К. Основания политической экономии. [Текст] / Карл Менгер; пер.с нем.// Избранные работы.М.: Издательский дом «Территория будущего», 2005.- 496 с.

17. Бём-Баверк О. фон. Капитал и прибыль; Т. 2: Позитивная теория капитала; Т. 3: Экскурсы. [Текст] / Ойген фон Бём-Баверк; пер. с англ.- Челябинск: Социум, 2010.- 916 с.

18. Васина Л.Л. О терминах «ценность» и «стоимость» в «Капитале» К. Маркса. [Текст] / Л.Л. Васина // Марксизм и современность. [Электронный pecypc]. http://marksizm.ucoz.ru/publ/51-1-0-698

URL:

19. Орєхова А. I. Ціннісноорієнтований підхід в системі управління підприємством. [Текст] / А. І. Орєхова // Вісник Сумського національного аграрного університету. Серія : Економіка і менеджмент. - 2016. - Вип. 1. - С. 49-53. - URL: http://nbuv.gov.ua/UJRN/Vsna ekon_2016_1_13.

20. Чиркин А.Н. Оценка бизнеса:

DOI 10.18664/338.47:338.45.v\%vi\%i.133645 основы, инструментарий, практика. [Текст] / Г.Б. Смирницкий, А.Н. Чиркин. К.: Издательство «Арт Экономи», 2013.312 c.

$$
\text { 21. Леонтян }
$$

M. A.

Поняття «компетенція» i «компетентність» у теорії освіти [Текст] / M. А. Леонтян // Наукові праці [Чорноморського державного університету імені Петра Могили комплексу «Києво-Могилянська академія»].- Сер. : Педагогіка. - 2012.Том 188.- Вип. 176.- С. 73 - 75.

22. Райан Б. Стратегический учет для руководителя [Текст]/ Боб Райан; пер. с англ.- М.: Аудит, ЮНИТИ, 1998.- 616 с.

23. Сериков А.В. Эффективность хозяйственной деятельности: определение, измерение, синергетическое управление. [Текст] / А.В. Сериков // Економічний вісник Донбассу.- 2011.- № 2(24).- С. 212 $-219$.

24. Фелпс Б. Умные бизнеспоказатели: Система измерений эффективности как важный элемент менеджмента [Текст] / Боб Фелпс; пер. с англ.- Днепропетровск: Баланс Бизнес Букс, 2004.- 312 с. 